\title{
Food Wars: Food, Intangible Cultural Heritage and International Trade
}

\author{
Valentina Vadi*
}

Who controls the food controls the people.

Henry Kissinger

[a]Introduction

Food preparation and even certain types of food can express deeply held cultural practices and values and constitute one type of intangible cultural heritage (ICH). The United Nations Educational Scientific and Cultural Organization (UNESCO) $)^{2}-$ the specialized agency of the United Nations which aims to contribute to peace and security by promoting international collaboration through education, science, and culture - has recently acknowledged the link between food and intangible heritage, listing a range of diverse diets in its list of intangible cultural heritage. Despite formal recognition at the international level, food preparation and associated cultural practices remain vulnerable to irreparable loss. 
Economic globalization risks jeopardising the protection of food as intangible cultural heritage and associated cultural practices. While economic globalization has spurred a more intense dialogue and interaction among nations - potentially promoting cultural diversity and even access to food - it can also jeopardize cultural traditions. The expansion of foreign direct investments in agriculture; increasing food processing and marketing through multinational corporations; the development of biotechnology and genetic engineering, and a growing international trade in food facilitated by the reduction of trade barriers can affect local cultural practices including those associated with food preparation. Moreover, trade in cultural products can lead to cultural commodification, cultural homogenization and even to cultural hegemony. Dominant cultures - also reflecting the global distribution of power - tend to predominate in the global markets (Friedman 1999 p8).

Food-related controversies have arisen during trade negotiations and have been brought before the World Trade Organization (WTO) ${ }^{3}$ Dispute Settlement Mechanism (DSM) where states have claimed that regulatory measures affecting their economic interests are in breach of the relevant international trade law provisions. These disputes highlight the emergence of a clash of cultures between global economic governance and the protection of local cultural pratices concerning food. Has an international economic culture emerged that emphasizes productivity and economic development at the expense of cultural wealth? Does the existing legal framework adequately protect cultural diversity vis-à-vis economic globalization? How have WTO dispute settlement bodies dealt with food wars? Should they take into account the cultural concerns of the affected communities? Or are cultural concerns merely to be conceived as a disguised form of protectionism? What steps can be taken to ensure mutual supportiveness between different legal regimes protecting food on the one hand and trade on the other? 
This chapter addresses these questions, illustrating the specific 'clash of cultures' between economic globalization and domestic food policies and focusing on the interplay between traders' rights and the protection of 'food heritage'. The chapter proceeds as follows. First, it briefly examines the conceptualization of food as a form of intangible cultural heritage. Second, it discusses and critically assesses the main features, promises and pitfalls of the UNESCO Convention on the Safeguarding of Intangible Cultural Heritage. Third, it examines recent food wars. Fourth, the question as to whether trade 'courts' are taking intangible cultural heritage into account will be addressed. Finally some conclusions will be drawn. By effectively analyzing food through the perspectives of cultural heritage law and international trade law this article productively brings two overlapping but frequently separate theoretical frameworks into conversation.

[a]Food as Intangible Cultural Heritage

Parodoxical as it may seem, something as perishable as food constitutes a living legacy of the past. Food 'constitutes a basic element of the culture of a people or of a community' (Maffei 2012a, p83) The transmission of food practices from one generation to the other contributes to constructing identity and memory of both individuals and communities. Food - its cultivation, preparation and communal consumption - can be a form of intangible cultural heritage (Brulotte and Di Giovine 2014).

The protection of intangible cultural heritage - meant as the wealth of cultural traditions and practices passed on from one generation to another-has long been neglected by international law. Early expressions of such protection were incorporated in minority protection treaty 
provisions and - albeit sparingly_ surfaced in the jurisprudence of the Permanent Court of International Justice (Pentassuglia 2009). In the aftermath of World War II, aspects of intangible heritage have been governed and/or touched upon by a number of international law instruments. For example, human rights instruments require states 'to take into account, as far as possible, cultural values attached to, inter alia, food and food consumption...' (UNCESC 2009, para16(e). Cases adjudicated before the International Court of Justice (ICJ) have touched upon the cultural practices and subsistence harvest of local communities. ${ }^{4}$

Only in the past decades, however, have specific instruments and programmes been devoted to the protection of food as a form of intangible heritage. In 1989 UNESCO issued a Recommendation on the Safeguarding of Traditional Culture and Folklore, ${ }^{5}$ listing policies that countries could implement to preserve their intangible cultural heritage. Yet, the recommendation was a 'soft' international instrument and had little impact due to its 'top-down' and 'state oriented' approach (Kurin 2004, p68). Very few states took action in this regard. In 2001 the launch of the Masterpieces of the Oral and Intangible Heritage programme — which established three rounds of proclamations of given traditions as representative 'Masterpieces' to raise awareness about intangible heritage - was very well received and paved the way for the elaboration of the CSICH (Aikawa-Faure 2009). Although no specific food preparations were included among the Masterpieces of Intangible Heritage, food figured prominently in the performance of some traditional cultural practices. ${ }^{6}$

[a]The Promises and Pitfalls of the CSICH

The 2003 UNESCO Convention on the Safeguarding of the Intangible Cultural Heritage $(\mathrm{CSICH})^{7}$ constitutes the principal instrument governing intangible cultural heritage at the 
international level. It defines intangible cultural heritage as 'the practices, representations, expressions, knowledge, skills - as well as the instruments, objects, artefacts and cultural spaces associated therewith - that communities, groups and, in some cases, individuals recognize as part of their cultural heritage' ${ }^{8}$ ' $[\mathrm{T}]$ ransmitted from generation to generation', intangible cultural heritage provides groups and communities with 'a sense of identity and continuity, thus promoting respect for cultural diversity and human creativity'. ${ }^{9}$ The convention considers solely 'such intangible cultural heritage as is compatible with existing international human rights instruments, as well as with the requirements of mutual respect among communities, groups and individuals, and of sustainable development ${ }^{\prime} \cdot{ }^{10}$ Although the convention does not expressly refer to food, its definition of intangible heritage is broad enough to encompass it.

The CSICH requires state parties to draw inventories of their intangible cultural heritage and to collaborate with local communities on various appropriate means of 'safeguarding' those traditions (Blake 2009). The UNESCO Committee established under the CSICH oversees two international lists: 1) the 'Representative List of the Intangible Cultural Heritage of Humanity', which includes, inter alia, the items already designated as Masterpieces of Oral and Intangible Heritage by UNESCO and is comparable to the World Heritage List; ${ }^{11}$ and 2) the 'List of Intangible Cultural Heritage in Need of Urgent Safeguarding, ${ }^{12}$ Food practices figure in both lists. Among the items included in the Representative List appear food practices such as the Gastronomic Meal of the French (France), ${ }^{13}$ the Traditional Mexican Cuisine (Mexico), ${ }^{14}$ the Mediterranean Diet (Spain, Greece, Italy and Morocco) ${ }^{15}$ and Washoku, traditional dietary cultures of the Japanese. ${ }^{16}$ Food also figures prominently as an element of other protected items, showing the deep connection between food and civilizations. Among the items included in the 
list of endangered intangible heritage appears the Paach Ceremony, a corn-veneration ritual celebrated in Guatemala. ${ }^{17}$

The Convention aims to remedy two structural imbalances within international law. First, the CSICH aims to remedy a gap in global cultural governance which has traditionally favoured the protection of tangible heritage such as monuments and sites over the protection of intangible heritage. Within UNESCO, the 1972 World Heritage Convention (WHC) ${ }^{18}$ has focused on the conservation of monuments and sites. Only recently has the WHC expanded its purview to comprehend elements of intangible heritage, and it now protects mixed forms of cultural heritage — such as cultural landscapes — which include both tangible and intangible features (Vadi 2012). Yet, the World Heritage List remains imbalanced, including more cultural than natural sites (Brown 2005).

Second, the CSICH aims to counterbalance the regulation of cultural resources by international trade law. In fact, globalization and trade in cultural products have the potential of promoting cultural exchange, but can also jeopardize local and regional cultural practices. The diffusion of a global mass culture has raised the fundamental question of whether 'valuable traditions, practices, and forms of knowledge rooted in diverse societies would survive the next generation' (Kurin 2004, p68). In this regard, the CSICH would counter the perceived commodification of culture, i.e., its reduction to a good or merchandise to be bartered or traded. Rather, the CSICH proposes an alternative view perceiving oral traditions and expressions, knowledge and practices concerning food as forms of intangible cultural heritage.

Despite its achievements, the CSICH risks both 'substantive overreach' (Broude 2015 p3) and procedural underachievement. Substantively, the definition of intangible cultural heritage is too broad and descriptive (Scovazzi 2008) risking an unwelcome 'politicization of culture' (Broude 
2015 p3). Procedurally, the listing approach 'convert[s] selected aspects of localized ... heritage into ... the heritage of humanity' (Kirshenblatt-Gimblett 2004, p57). Yet, inventories do not do justice to intangible cultural heritage meant as a living phenomenon. Rather, the listing approach risks 'misconceiving culture as atomistic items' and freezing this living heritage (Lubina 2009, p50). Furthermore, while inventories and lists may recognize various traditions, they will hardly save them (Kurin 2004, p74).

Problems of conflict and/or coordination between the CSICH and other international normswhether customary or conventional—-have shown additional procedural shortcomings of the $\mathrm{CSICH}$. The interaction between the $\mathrm{CSICH}$ and other international law regimes relates to the general question as to whether international law is a fragmented system or not (ILC 2006) and raises the specific question as to whether the protection of intangible cultural heritage shold be taken into account in the implementation of other international law regimes. In fact, while the CSICH can (and has) overlap(ped) with international trade law, it does not provide a binding dispute settlement mechanisms. Not surprisingly, food-related disputes have been brought before the WTO DSM. The next section will explore some food wars where the protection of intangible cultural heritage clashes with the promotion of free trade.

\section{[a]Food Wars}

Food-related trade conflicts and disputes do not have a typical form and may relate to different areas of international trade law, ranging from international intellectual property law to agricultural law. For instance, although not all intellectual property constitutes intangible heritage, and vice versa (Gervais 2003-2004, p633), there is significant interaction between the 
CSICH and the Agreement on Trade Related Aspects of Intellectual Property Rights (TRIPS Agreement). ${ }^{19}$ In this regard, the CSICH provides for a compatibility clause, stating that none of its provisions can be interpreted as affecting 'the rights and obligations of States Parties deriving from any international instrument relating to intellectual property rights. ${ }^{, 20}$ Yet, the CSICH lacks specific rules over ownership and control over intangible cultural heritage (Kearney 2009, p216). In turn, the TRIPS Agreement fails to recognise the non-economic interests associated with intangible assets.

The inadequacy of the TRIPS Agreement to safeguard intangible cultural heritage is particularly evident with regard to controversies and disputes raised by the patenting by multinational corporations of ethnic food traditionally consumed by local communities (Woods 2002-2003, p123). Without a sensible remodeling, intellectual property rights risk overprotecting individual economic interests, while ignoring the collective entitlements of the relevant cultural communities.

Another area of connection among food, cultural practices and intellectual property is that of geographical indications. Geographical indications (GIs) - such as Parmigiano Reggiano, Champagne, and Gouda - are signs used to identify products which come from these places and whose quality reputation or other characteristic depends on these specific geographical locations. Gis can be a possible vector for protecting intangible cultural heritage (Gangjee 2015). By protecting regional food products which have acquired a strong reputation among consumers and have been produced using centuries-old manufacturing techniques, GIs can indirectly protect the intangible cultural heritage associated with the production of these goods. Three dimensions of culture are relevant to GIs: 1) the culture of producing a given type of food; 2) the culture of 
consuming certain food; and 3) 'the culture of identity in which a good is somehow representative of a group's cultural identity' (Broude 2015 p15).

However, there is a transatlantic divide over the protection of GIs. While the TRIPS Agreement provides the protection of GIs in order to avoid misleading the public and to prevent unfair competition $^{21}$ and provides for some limited exceptions, ${ }^{22}$ it does not provide a detailed regulation of the same. While European states have protected certain foodstuffs originating from given geographical locations since the $15^{\text {th }}$ century (Shimura 2010, p.129), other countries consider them as obstacles to trade. For instance, when the European Commission considered a U.S. request to drop a ban on import into Europe of American wines bearing the label chateau, a term used mainly on wines from Burgundy in eastern France, French wine producers contended that American competitors should not be allowed to sell chateau-type wine in the EU, as their production standards differ from the French ones. In France, wine labelled chateau is entirely made from grapes grown on a terroir - a specific area of land - supposedly giving it a unique character and flavour (Lauter 2012). According to French rules, only wine from grapes grown on the property and made into wine in facilities on the property can bear the chateau label (Cody 2012). According to French winemakers, '[t]his is a guarantee of quality..., a declaration to the buyer that [s]he is sharing in the heritage that gave rise to h[er] wine' (Cody 2012). Instead, American wines are made with a mixture of grapes purchased from different growers, as the American labelling system 'traditionally highlights grape variety, rather than where the fruit was grown' (Cody 2012). Therefore, French producers claim that American producers should not be allowed to have chateau on the label.

The divergent approaches to geographical indications of the US and the EU have fostered intense conflicts at different venues. At the multilateral level, WTO members are debating the adoption 
of a multilateral register for wines and spirits. Some countries, including the EU, are pushing for a register with binding effects, while other countries, including the United States, are pushing for a non-binding system under which the WTO would simply be notified of the members' respective geographical indications. This divergence is also playing a central role in the negotiations of the Transatlantic Trade and Investment Partnership (TTIP) - the free trade agreement currently being negotiated between the European Union and the United States. While the European Union wants to stop American producers from being able to commercialise and label products with their protected names, the United States would favour free trade (Bonadio 2015). This lack of protection - the European negotiators argue - allows an unacceptable exploitation of European intangible heritage, and affects the economic interests of European producers. Conversely, the US negotiators contend that such names have become generic and cannot be monopolised by anyone. Moreover, EU-style legal protection would constitute a barrier to trade, allow monopolies and ultimately increase final prices for consumers. Finally, the EU system would be unfair because European immigrants have long produced such products, thus sharing the same intangible cultural heritage.

Not only has the intense debate over GIs an evident economic component, but it also has a cultural character. In fact, proponents of GIs conceive food as something more than a tradable commodity but as an artifact characterised by both visible features and intangible cultural qualities related to the traditional manufacturing processes and the place of origin. In other words, 'as a forged painting and the original one may not differ at all materially, while still being quite different artworks, so a GI cannot be equated to its material constitution: some aspects of its making are key to its identity' (Borghini 2014, p. 1118). 
The interaction between international economic law and the protection of food qua intangible heritage includes other areas beyond the purview of intellectual property. For instance, the EU ban on the commercialisation of seal products caused a cultural skirmish across the Atlantic. ${ }^{23}$ As Europeans perceive the hunting of seals to be morally objectionable, the EU has banned the trade in seal products except those derived from hunts traditionally conducted by the Inuit and other indigenous communities for cultural and subsistence reasons ${ }^{24}$ Seals constitute the most important component of an Inuit diet (Searles 2002) and indigenous hunting practices constitute a form of intangible cultural heritage deemed essential to preserve indigenous way of life. Canada and Norway brought claims against the EU before the WTO Dispute Settlement Body (DSB), contending that the EU seal regime was inconsistent with the European Union's obligations under the General Agreement on Tariffs and Trade 1994 (GATT 1994) ${ }^{25}$ and under the Technical Barriers to Trade (TBT) Agreement. ${ }^{26}$ Specifically, Canada and Norway argued, inter alia, that the indigenous communities condition (IC condition) violated the nondiscrimination obligation under Article I:1 and III:4 of the GATT 1994. According to Canada and Norway, such conditions accord seal products from Canada and Norway treatment less favourable than that accorded to like seal products of domestic origin as well as those of other foreign origin, in particular from Greenland.$^{27}$ In fact, the majority of seals hunted in Canada and Norway would not qualify under the exception, while most, if not all, of Greenlandic seal products would satisfy the requirements under the IC exception. ${ }^{28}$ The panel and the Appellate Body held, inter alia, that the exception provided for indigenous communities under the EU Seal Regime accorded more favourable treatment to seal products produced by indigenous communities than that accorded to like domestic and foreign products $^{29}$ in breach of Articles I:1 and III:4 of the GATT 1994. Little reference was made to the various instruments which protect 
indigenous cultural practices at the international law level, ${ }^{30}$ including the 2007 United Nations Declaration on the Rights of Indigenous Peoples (UNDRIP), ${ }^{31}$ Despite the reference to these instruments, however, the panel concluded that the design and application of the IC measure was not even-handed because the IC exception was available de facto to Greenland. ${ }^{32}$

Another sector in which cultural clash between free trade and food-related cultural practices takes place is that of agriculture. The WTO's Agreement on Agriculture ${ }^{33}$ is based on the market liberalization model and efficiency criteria (Smith 2011, p159). It does 'not allow farmers to maintain their current methods of production solely on cultural or environmental grounds, if those methods prevent the farmers from efficiently adjusting their production in line with market forces' (Smith 2011, p168). Rather, the WTO regards agriculture 'as an economic sector like any other industrial sector' (Smith 2011, p159). In some countries, the liberalization of the market opening the markets to highly subsidized agriculture - has meant that local farmers have to compete with heavily subsidized imports (Hauter 2007, p1071). Competition has driven down the price and forced these farmers out of business. This phenomenon has also involved products central to a country's culture (Smith 2009). For example, the influx of highly subsidized corn from the United States undermined the ability of Mexican farmers to grow corn, a crop that Maxican have cultivated for centuries (Smith 2011, 161).

Another area of cultural resistance, in which the clash between free trade and cultural attitudes is particularly evident, is that related to food safety. The WTO Sanitary and Phytosanitary Agreement $^{34}$ addresses the interest of member states in assuring that their citizens are being supplied with safe food encouraging member states to base sanitary and phytosanitary measures on internationally accepted scientific standards (Beghin 2014, p.7). Problems have arisen with regard to the interpretation of scientific evidence. While the precautionary approach to risk 
management is a general principle of EU law, entailing that given products are prohibited until they are proven safe, on the other side of the Atlantic, it goes the other way round and products have to be proven unsafe to be banned. These different approaches to risk and food safety based on different cultural understandings of food - have given rise to a number of disputes at the WTO, concerning hormones, genetically modified organisms (GMOs) and others. Trade experts tend to see safety regulations and cultural concerns as forms of protectionism and technical trade barriers rather than legitimate concerns.

[a]Conclusions

Food is at the heart of civilizations, given its importance for human subsistence, well-being and human flourishing. Nutrition plays a cultural role in shaping a community's and a person's specific identity (Korthals 2008, p445) and, in certain cases, food preparation and consumption can constitute a form of intangible heritage. Since 2003, ICH has been ingrained in a dedicated international law instrument, the CSICH. Despite some achievements, the CSICH is characterised by substantive overreach and procedural underachievement. Not only does it fail to ensure adequate safeguarding of intangible heritage, as it constitutes a 'de facto soft law instrument in formal hard law clothing' (Broude 2015 p3), but it also fails to provide a meaningful forum to address ICH-related trade disputes. Despite the recognition of food as an element of intangible cultural heritage, economic globalization risks jeopardising cultural practices by altering food consumption patterns. 
In general terms, food-related trade disputes are characterized by the need to balance the protection of cultural practices associated with food and economic interests associated with trade. Many such controversies arise during trade negotiations or are brought before the WTO dispute settlement mechanism. The WTO is a legally binding and highly effective regime which demands states to promote and facilitate free trade. The WTO is based on a free-market paradigm and its rules are about trade (Smith 2011, p176). It is not interested in local communities, food, culture and farming techniques as such. These issues are considered as noneconomic concerns and therefore remain at the margins of the regime (Smith 2011, p176). Not surprisingly, trade 'courts' have paid very little attention to the cultural aspects of food-related disputes.

\section{[a]References}

Aikawa-Faure, N. (2009) 'From the Proclamation of Masterpieces to the Convention for the Safeguarding of Intangible Cultural Heritage', in L. Smith and N. Akagawa (eds.) Intangible Heritage, Routledge, London

Beghin, J. (2014) 'The Protectionism of Food Safety Standards in International Agricultural Trade', Agricultural Policy Review 1, 7-9

Blake, J. (2009) 'UNESCO's 2003 Convention on Intangible Cultural Heritage: The Implication of Community Involvement in "Safeguarding" in L. Smith and N. Akagawa (eds.) Intangible Heritage, Routledge, London

Bonadio, E. (2015) 'Why Europe and the US are Locked in a Food Fight over TTIP', The Conversation, 7 August

Borghini, A. (2014) 'Geographical Indications, Food and Culture', in P.B. Thompson and D.M. Kaplan (eds), Encyclopedia of Food and Agricultural Ethics, Springer, Heidelberg

Broude, T. (2015) 'A Diet too Far? Intangible Cultural heritage, Cultural Diversity, and Culinary Practices' in I. Calboli and S. Radavan (eds), Protecting and Promoting Diversity with Intellectual Property Law, Cambridge, Cambridge University Press

Brown, M.F. (2005) 'Heritage Trouble: Recent Work on the Protection of Intangible Cultural Property' International Journal of Cultural Property 12, 40-61

Brulotte R.L. and Di Giovine M.A. (2014) 'Introduction: Food and Foodways as Cultural Heritage', in R.L. Brulotte and M.A. Di Giovine (eds) Edible Identities: Food as Cultural Heritage, Ashgate 
Cody, E. (2012) 'Chateau' isn't made in America, French Vintners Say', Washington Post, 24 September

Friedman, T.L. (1999) The Lexus and the Olive Tree, New York, Farrar

Gangjee, D.S. (2015) 'Geographical Indications and Cultural Rights: The Intangible Cultural Heritage Connection?' in C. Geiger (ed), Research Handbook on Human Rights and Intellectual Property, Edward Elgar, Cheltenham

Gervais, D. (2003-2004) 'Spiritual but Not Intellectual-The Protection of Sacred Intangible Traditional Knowledge', Cardozo Journal of International and Comparative Law 11, 633

Hauter, W. (2007) 'The Limits of International Human Rights Law and the Role of Food Sovereignty in Protecting People from Further Trade Liberalization under the Doha Round Negotiations' Vanderbilt Journal of Transnational Law 40, 1071

International Law Commission (2006) Report of the Study Group of the International Law Commission, Fragmentation of International Law: Difficulties Arising from the Diversification and Expansion of International Law, U.N. Doc. A/CN.4/L.682, 13 April

Kearney, A. (2009) 'Intangible Cultural Heritage (Global Awareness and Local Interest)', in L. Smith and N. Akagawa (eds) Intangible Heritage, Routledge, London

Kirshenblatt-Gimblett, B. (2004) 'Intangible Heritage as Metacultural Production', 56 Museum International (2004) 52-65

Korthals, M. (2008) 'Ethics and Politics of Food: Toward a Deliberative Perspective' Journal of Social Philosophy 39 (2008) 445-463

Kurin, R. (2004) 'Safeguarding Intangible Cultural Heritage in the 2003 UNESCO Convention: a Critical Appraisal', Museum International, 66-77

Lauter, D. (2012) 'French Winemakers concerned over "Chateau" Change', The Telegraph, 16 September

Lubina, K. (2009) 'Protection and Preservation of Cultural Heritage in the Netherlands in the 21 st Century', Electronic Journal of Comparative Law 13, 1-62

Maffei, M.C. (2012a) 'Food as a Cultural Choice: A Human Rights to Be Protected?', in S. Borelli and F. Lenzerini (eds) Cultural Heritage, Cultural Rights, Cultural Diversity, Martinus Nijhoff, Leiden/Boston

Pentassuglia, G. (2009) Minority Groups and Judicial Discourse in International Law: A Comparative Perspective, Martinus Nijhoff Publishers, Leiden

Scovazzi, T. 'La notion de patrimoine culturel de l'humanité dans les instruments internationaux', in J.A.R. Nafziger and T. Scovazzi (eds) Le patrimoine culturel de l'humanité/The Cultural Heritage of Mankind, Brill, Leiden

Searles, E. (2002) 'Food and the Making of Modern Inuit Identities' Food \& Foodways: History \& Culture of Human Nourishment 10, 55-78

Shimura, K. (2010) 'How to Cut the Cheese: Homonymous Names of Registered Geographic Indicators of Foodstuffs in Regulation 510/2006', Boston College International \& Comparative Law Review 129

Smith, F. (2009) Agriculture and the WTO: Towards a New Theory of International Agricultural Trade Regulation, Cheltenham, UK, Edward Elgar

Smith, F. (2011) 'Indigenous Farmers' Rights, International Agricultural Trade and the WTO', Journal of Human Rights and the Environment 2, 157-177

United Nations Committee on Economic, Social and Cultural Rights (UNCESC) (2009), General Comment No. 21, Right of Everyone to Take Part in Cultural Life (article 15, Para. 1(a), 
of the International Covenant on Economic, Social and Cultural Rights), UN doc. E/C.12/GC/21, 21 December

UNESCO (2005) Masterpieces of the Oral and Intangible Heritage of Humanity-

Proclamations 2001, 2003, 2005, United Nations, Paris.

Vadi, V. (2012) 'The Protection of Cultural Landscapes and Indigenous Heritage in International Investment Law', in L. Westra, C. Soskolne and D. Spady (eds.) Human Health \& Ecological Integrity - Ethics, Law and Human Rights, Earthscan, London

Woods, M. (2002-2003) 'Food for Thought: The Biopiracy of Jasmine and Basmati Rice', Albany Law Journal of Science and Technology 13, 123

\footnotetext{
* Professor of International Economic Law, Lancaster University. The author may be contacted at v.vadi@lancaster.ac.uk.

${ }^{2}$ Constitution of the United Nations Educational, Scientific and Cultural Organization (UNESCO Constitution), 16 November 1945, in force 4 November 1946, 4 UNTS 275.

${ }^{3}$ Agreement Establishing the World Trade Organization (Marrakesh Agreement), 15 April 1994, 1867 UNTS 154; 33 ILM 1144 (1994).

${ }^{4}$ A couple of ICJ cases referred to local fishing customs or practices. One could contend that fishing practices constitute economic and subsistence activities rather than cultural practices. Therefore, such cases would not focus on intangible cultural heritage per se. Yet, human rights courts have acknowledged that hunting and fishing practices can have a cultural component, contributing to the identity of given local communities. In any case these cases show the willingness of the ICJ to take into account local practices of fishing communities. See e.g. Pulp Mills on the River Uruguay (Argentina v. Uruguay), Judgment of 20 April 2010, I.C.J. Reports 2010, p. 14 para 171 (referring to 'pre-existing uses of the river'); Case Concerning Maritime Delimitation in the Area between Greenland and Jan Mayen (Denmark v. Norway) Judgment of 14 June 1993, I.C.J. Reports 1993, p. 38, para 73 (referring to the local fishing practices of migratory stocks).

${ }^{5}$ Recommendation on the Safeguarding of Traditional Culture and Folklore, 15 November 1989, available at http://portal.unesco.org/en/ev.php-URL_ID=13141\&URL_DO=DO_TOPIC\&URL_SECTION=201.html (accessed on 15 May 2015).

${ }^{6}$ For instance, Mexico proclaimed the Indigenous Day of the Dead (el Día de los Muertos) as a masterpiece of its intangible heritage. The festivity takes place each year at the end of October to the beginning of November to commemorate the transitory return to Earth of deceased relatives and loved ones and mark the completion of the annual cycle of cultivation of maize, the country's predominant food crop. Locals prepare the deceased's favourite dishes, believing that the dead can bring prosperity (e.g. an abundant maize harvest) depending on how well the rituals are performed. (UNESCO 2005 p66)

${ }^{7}$ Convention for the Safeguarding of the Intangible Cultural Heritage (CSICH), 17 October 2003, 2368 UNTS.

${ }^{8} \mathrm{CSICH}$, Article 2(1).

${ }^{9} \mathrm{CSICH}$, Article 2(1).

${ }^{10} \mathrm{CSICH}$, Article 2(1).

${ }^{11}$ CSICH, Article 16.

${ }^{12} \mathrm{CSICH}$, Article 17.

${ }^{13}$ UNESCO doc. ITH/10/5.COM/CONF.202/Decisions, 19 November 2010, p. 21.

${ }^{14}$ UNESCO doc. ITH/10/5.COM/CONF.202/Decisions, 19 November 2010, p. 45.

${ }^{15}$ UNESCO, Decision 8 COM8.10.

${ }^{16}$ UNESCO, Decision 8 COM8.17.

${ }^{17}$ UNESCO, Decision 8.COM.

${ }^{18}$ Convention Concerning the Protection of the World Cultural and Natural Heritage. Paris, 16 November 1972. 1037 UNTS 151, 11 ILM 1358.

${ }_{19}$ Agreement on Trade-Related Aspects of Intellectual Property Rights (TRIPS Agreement), 15 April 1994, Marrakesh Agreement Establishing the World Trade Organization, Annex 1C, 1869 UNTS 299, 33 ILM 1197 (1994).
} 
${ }^{20} \mathrm{CSICH}$, Article 3(b).

${ }^{21}$ TRIPS Agreement, Article 22.

${ }^{22}$ TRIPS Agreement, Article 24.

${ }^{23}$ European Communities-Measures Prohibiting the Importation and Marketing of Seal Products, Reports of the Panel, 25 November 2013, WT/DS400/R, WT/DS401/R. European Communities-Measures Prohibiting the Importation and Marketing of Seal Products, Reports of the Appellate Body, 22 May 2014.

${ }^{24}$ Regulation (EC) 1007/2009 of the European Parliament and of the Council of 16 September 2009 on Trade in Seal Products, 2009 OJ (L. 286) 36.

${ }^{25}$ General Agreement on Tariffs and Trade 1994, 15 April 1994, Marrakesh Agreement Establishing the World Trade Organization, Annex 1A, 1867 UNTS 187.

${ }^{26}$ Agreement on Technical Barriers to Trade, 15 April 1994, Marrakesh Agreement Establishing the World Trade Organization, Annex 1A, 1868 UNTS 120.

${ }^{27}$ European Communities-Measures Prohibiting the Importation and Marketing of Seal Products, Reports of the Panel, para. 7.2.

${ }^{28}$ Ibid. paras. 7.161 and 7.164 .

${ }^{29}$ Ibid. para. $8(2)$.

${ }^{30}$ Ibid. para. 7.292.

${ }^{31}$ United Nations Declaration on the Rights of Indigenous Peoples, A/RES/61/295, (2007).

32 European Communities-Measures Prohibiting the Importation and Marketing of Seal Products, Reports of the Panel, para. 7.317

${ }_{33}$ Agreement on Agriculture, 15 April 1994, Marrakesh Agreement Establishing the World Trade Organization, Annex 1A, 1867 UNTS 410.

${ }^{34}$ Agreement on the Application of Sanitary and Phytosanitary Measures, 15 April 1994, Marrakesh Agreement Establishing the World Trade Organization, Annex 1A, 1867 UNTS 493. 